\title{
REGENERATION OF NARDUS STRICTA SUBALPINE GRASSLANDS IN THE GIANT MOUNTAINS (KRKONOŠE)
}

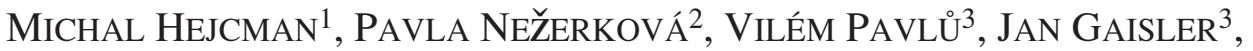 \\ THEODOR LOKVENC ${ }^{4}$, LENKA PAVLU ${ }^{5}$ \\ ${ }^{1}$ Czech University of Agriculture in Prague \\ Department of Crop Production and Grassland Management \\ Kamýcká 957, 16521 Praha 6 - Suchdol, Czech Republic \\ e-mail: hejcman@af.czu.cz \\ ${ }^{2}$ Czech University of Agriculture in Prague, Institute of Tropics and Subtropics \\ Kamýcká 129, 16521 Praha 6 - Suchdol, Czech Republic \\ e-mail:nezer@itsz.czu.cz \\ ${ }^{3}$ Research Institute of Crop Production, Prague-Ruzyně \\ Grassland Research Station, Rolnická 6, 46001 Liberec, Czech Republic \\ e-mail:pavlu@vurv.cz \\ ${ }^{4}$ Forest and Game Management Research Institute, Forest Research Station \\ Na olive 550, 51773 Opočno, Czech Republic \\ 5 Jizerské Mts. Protected Landscape Area Administration \\ U Jezu 10, CZ-460 01 Liberec, Czech Republic
}

(Received: November 17, 2004. Accepted: March 17, 2005)

\begin{abstract}
The origin of Nardus stricta dominated subalpine grassland (Nardo-Caricion rigidae alliance) is a frequently discussed topic in the Giant Mountains (Krkonoše in the Czech Republic). Many researchers considered them, as secondary stands arisen after Pinus mugo removal and by consequent oligotrophization of original plant communities, caused by long-term rough grazing and hay making activities without manuring. On the contrary, they are recognized as natural due to inability of generative reproduction of $N$. stricta and the very slow vegetative spread there. The aim of this study was to find proofs for generative reproduction of mat grass in subalpine conditions of the Giant Mountains. We identified a Pinus mugo nursery with arable land abandoned in 1956 and compared its vegetation with that of the surrounding area. Dense and homogenous sward dominated by $N$. stricta developed during the succession on the old arable land for 48 years, and it is an indisputable proof of generative reproduction of $N$. stricta there. Synthesizing historical facts on human activities in the past and the results of our contemporary vegetation analysis, we conclude that the Nardo-Caricion rigidae grassland was capable to spread relatively quickly, when agricultural activities above the upper timber line were introduced.
\end{abstract}

KEY WORDS: generative reproduction, Nardus stricta, Nardo-Caricion rigidae, arable land succession, Giant Mountains.

\section{INTRODUCTION}

The origin of Nardus stricta dominated subalpine grassland (Nardo-Caricion rigidae alliance) is a frequently discussed topic in the Giant Mountains (Krkonoše). This species' poor vegetation is wide spread on the western and eastern subalpine plateaus there, then fragmentally in the Kralický Sněžnik and the Jeseníky Mts. in the Czech Republic (Krahulec et al. 1996). According to Krahulec (1985), the Nardo-Caricion rigidae alliance represents a significant relict type of grassy tundra vegetation there, with center of natural distribution in Scandinavia, Scotland and Island. Carici fyllae-Nardetum is the only association of that alliance due to relatively low heterogeneity of $N$. stricta subalpine sward in the Giant Mountains (Jeník 1961). Carici rigidae-Nardetum is its synonym generally accepted in Polish literature (Matuszkiewicz, Matuszkiewicz 1974; Fabiszewski, Wojtuń 2001).

The majority of mat grass stands above the upper tree limit were generally considered by many authors as secondary, which arose after Pinus mugo removal and by consequent oligotrophisation of original plant communities, cau- 


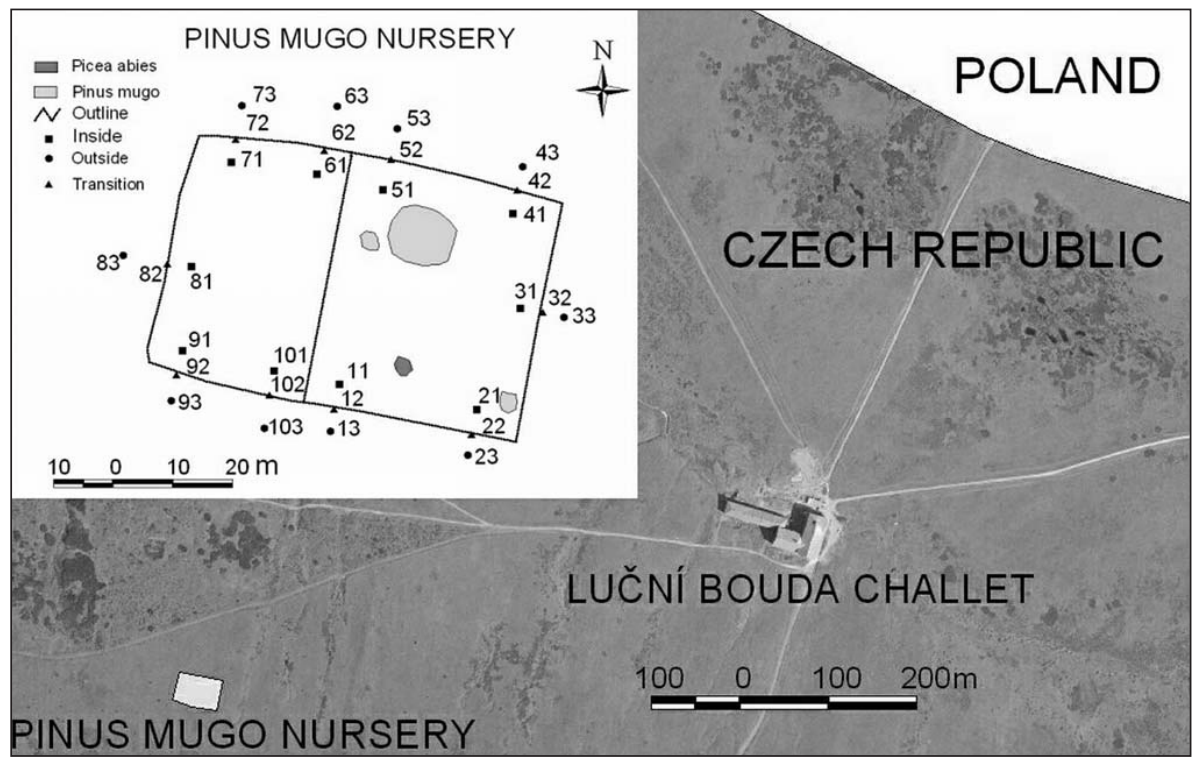

Fig. 1. Position of the nursery in the orthophotomap taken in 2000 and detail plan of relevés collection. sed by long term rough grazing and hay making activities without manuring (Lokvenc 1960, 1878, 2001; Jeník 1961; Matuszkiewicz, Matuszkiewicz 1975; Štursa 1983). Štursová $(1974,1985)$ studied the effect of mineral fertilization on structure of Carici fyllae-Nardetum sward in the eastern part of the mountains near the chalet Lučni Bouda. Basing on the long-term reaction of the sward, she concluded on low dynamics of $N$. stricta above the upper tree line and presumed its inability to colonize the bare ground after sward removal. She also documented the incapability of generative reproduction of $N$. stricta on the example of trenches excavated before the World War II by the Czechoslovak army. The trenches stayed partly without vegetation cover or were colonized by Avenella flexuosa or Calamagrostis villosa, not by $N$. stricta, although this species was the most frequent in the neighborhood during 40 years of natural succession. With respect to these facts, she considered Carici fyllae-Nardetum grassland as natural vegetation, which was, however, probably only partly enlarged by agricultural activities in the past. In the last few decades, Calamagrostis villosa and Molinia caerulea expansion was recorded there (Wágnerová 1991; Lokvenc 1996; Fabiszewski, Wojtun 2001). Higher nitrogen deposition is the generally accepted reason for the increase of these species, disregarding defoliation activities performed there before World War II. Hejcman et al. (2003) investigated the effect of mowing on $C$. villosa stands in the Western subalpine plateau of the Giant Mountains. The negative reaction of C. villosa to the defoliation led them to consider its present increase, at least partly as a natural succession after cessation of regular management. It is obvious that agricultural activities performed above the upper tree line for at least 500 years had to cause $C$. villosa reduction and $N$. stricta increase. Hendrych (2001) raised a presumption on the $N$. stricta quick increase during the $17^{\text {th }}$ and $18^{\text {th }}$ centuries. Vegetative spread of N. stricta is very slow there (Štursová 1974, 1984), therefore the generative reproduction had to take part in the process of grassland succession under management activities. This statement on the possibility of generative reproduction of $N$. stricta is in sharp discrepancy with Štursová's (1985) conclusions on inability of this grass to reproduce generatively above the upper tree limit. With respect to that, the aim of our study was to prove the ability of generative reproduction of mat grass in subalpine conditions of the Giant Mountains.

\section{MATERIALS AND METHODS}

\section{Study site}

The present study was performed on the Bílá Louka meadow, $750 \mathrm{~m}$ southwest from Luční Bouda chalet (Fig. 1) in the eastern part of the Giant Mountains (50 43'55' $\mathrm{N}$, $15^{\circ} 41^{\prime} 10^{\prime}$ ' W, Czech Republic). According to Soukupová et al. (1995), the investigated area belongs to the vegetation zone of arctic-alpine tundra. The study area lies at an altitude of $1435 \mathrm{~m}$ a.s.1. The soil types are podzols developed on medium grain porphyric granite. The mean annual temperature is $2^{\circ} \mathrm{C}$ and the mean annual precipitation is $1380 \mathrm{~mm}$ (Vrbatova bouda Meteorological Station). Basing on historical records and photographs we localized an abandoned Pinus mugo nursery. The nursery was used for production of Pinus mugo seedlings in purpose of subalpine grassland reforestation. The reforestation was performed on stands where $P$. mugo shrubs were removed in the past to enlarge the area for grazing and hay making. The quality of seedlings was low and their production too expensive, thus the area was abandoned in 1908 (Lokvenc 1983). The nursery was experimentally reestablished in 1952 and again abandoned in 1956 for low quality and insufficient annual growth to seedlings. The nursery was abandoned without sowing of any seed mixture, and a natural succession of the arable land was therefore allowed there in 1908 and 1956. The state of the nursery in 1954, two years before the second abandonment, is visible in Figure 2. The nursery was rectangle $50 \times 34 \mathrm{~m}$. ArcView 3.2 software was used for presentation of study area and data collection design to enable the repetition of data collection in the future.

\section{Plant species composition}

Relevés were collected in ten triplets. The first plot of the each triplet was placed inside of the nursery (I), the second in the clearly visible transition zone (T) between two plots and the third one outside $(\mathrm{O})$ (see Fig. 1). Detailed description of compared plots is in Table 1. Relevés were collected in squares $4.2 \times 4.2 \mathrm{~m}\left(17.65 \mathrm{~m}^{2}\right)$ in I and $\mathrm{O}$ plots, 


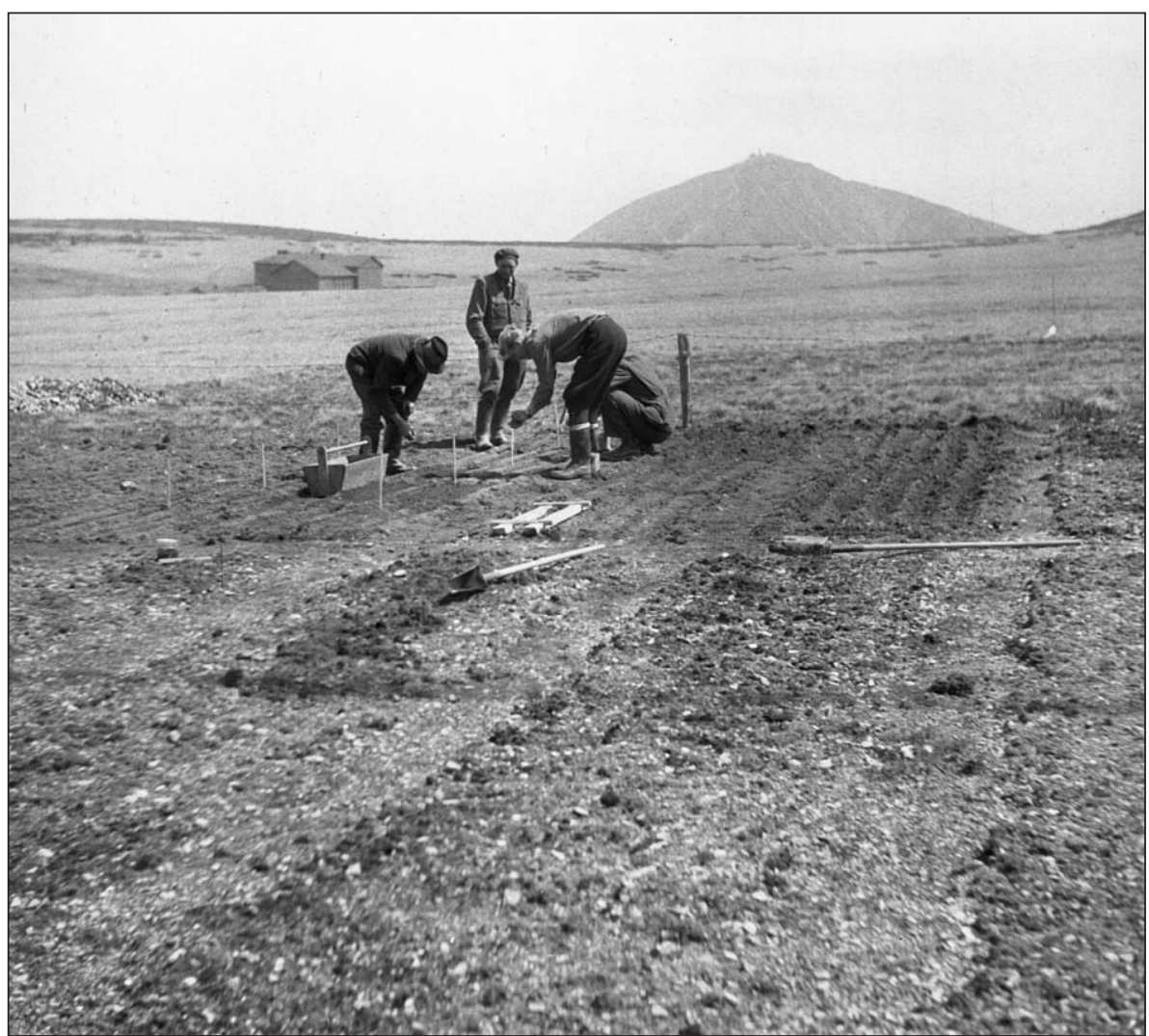

Fig. 2. Pinus mugo nursery in 1954. Inside of the nursery is arable land, transition zone with sods removed from the nursery is in the right side of the picture. and in rectangles $2.8 \times 6.3 \mathrm{~m}\left(17.65 \mathrm{~m}^{2}\right)$ in T plots. We used different sampling plot dimensions, because the transition zone was up to $3 \mathrm{~m}$ wide only. Coverage of all present species was visually estimated in percentages at the end of July 2004. Nomenclature: Kubát et al. (2002), Krahulec et al. (1996) for phytocoenological units.

\section{Compressed sward height}

To evaluate sward heterogeneity, within each plot and also among three investigated stands, we used compressed sward height parameter measured by rising plate meter. This method is frequently used for measurement of grazing intensity and variability of grazing on pastures (Correl et al. 2003; Pavlů et al. 2003). Ten measurements were performed within each relevé for calculation of mean sward height and range of heights (maximal height minus minimal height). Range of height was calculated to analyze sward variability within each relevé.

\section{Data analysis}

Redundancy analysis (RDA) in the CANOCO program (Ter Braak and Šmilauer 1998) was used to evaluate multivariate plant species data. Redundancy analysis is a direct gradient analysis based method on the assumption of linear response and was used because data sets were relatively homogeneous. Permutations in Monte Carlo permutation test were performed completely at random in each triplet.
499 permutations were performed in all analyses. After obtaining significant results of RDA analyses, ANOVA was used to reveal differences in coverage for the most frequent species. Mean sward height, range of heights, and number of species were analyzed by one-way ANOVA. Tukey HSD test was used for multiple comparisons in case of significant ANOVA results.

\section{RESULTS}

\section{Plant species composition}

We recorded 18 vascular plant species and moss Polytrichum commune Hedw. in the collected relevés. Nardus stricta, Avenella flexuosa, Carex bigelowii, Deschampsia cespitosa, Anthoxanthum alpinum, Calamagrostis villosa, Solidago virgaurea subsp. minuta. Luzula sudetica and Veratrum album subsp. lobelianum were the most frequent species. Hieracium alpinum, Calluna vulgaris, Galium saxatile, and Polygonum bistorta occurred in less than one third of collected samples. Silene dioica, Festuca supina, Gentiana asclepiadea, Silene vulgaris and Carex canescens were recorded only in one sample.

We revealed very homogenous and the densest sward of all compared stands developed on the abandoned arable land inside the Pinus mugo nursery within 48 years. Mean total coverage was 95,80 and $84 \%$ inside, outside of the

TABLE 1. Description of compared areas.

\begin{tabular}{ll}
\hline Abbreviation & Description of the area \\
\hline $\mathrm{I}$ & Pinus mugo nursery, stones and sward were removed in 1905 and again in 1952, natural colonization of arable land was there since 1956. \\
$\mathrm{O}$ & Outside of the nursery, vegetation received no plowing, sward removal or further destructive impacts. \\
$\mathrm{T}$ & Transition zone, stones and swards removed from the nursery were put there in 1905 and again in 1952. \\
\hline
\end{tabular}


Total coverage
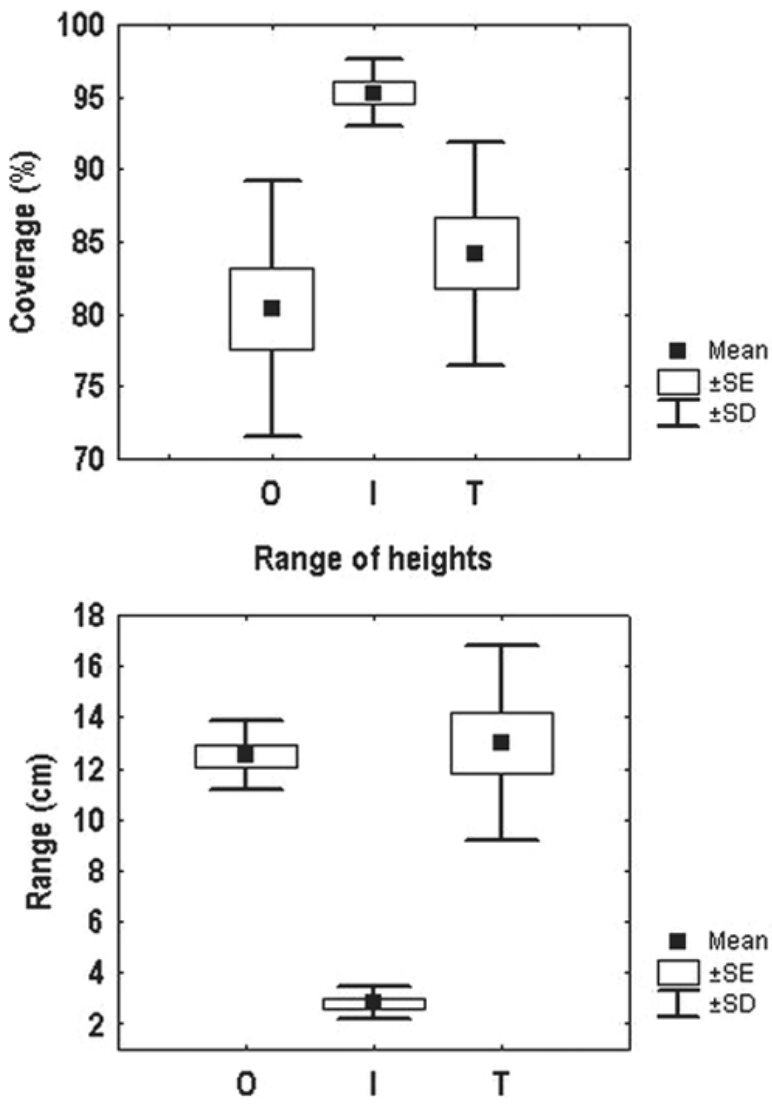

nursery and in the transition zone respectively (Fig. 3). Differences in total coverage were significant between I$\mathrm{O}$ and I-T stands (Table 2). To reveal differences in sward structure, we performed RDA analyses of collected relevés. Analysis 1 (Table 3 ) revealed that at least one stand differed significantly from other ones. Relevés position explained together $72.6 \%$ of species data variability. Analyses 2-4 revealed differences between all combinations of stands. To show differences among stands, we analyzed the most common species separately by one-way ANOVA (Table 2, Fig. 4). Coverage of $N$. stricta was the highest inside, $A$. flexuosa, D. cespitosa and $C$. villosa in the transition zone, and $C$. bigelowii outside of nursery. Mean recorded cover of N. stricta was 80,34, and 5\%, A. flexuosa 16, 32, and $44 \%, D$. cespitosa 1,1 , and $15 \%$, C.villosa $0.4,1$ and $9 \%$ and $C$. bigelowii 1,18 , and $14 \%$ in I, O, and T stands re-

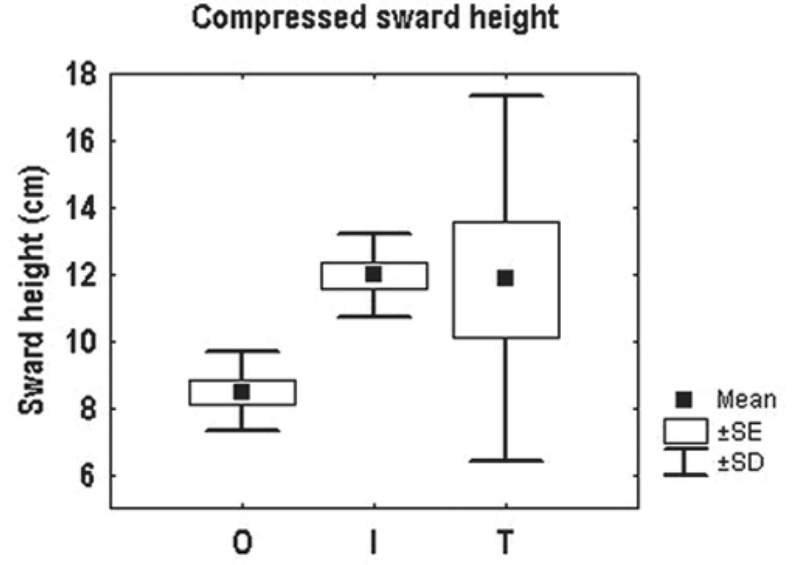

Fig. 3. Total coverage, compressed sward height, and range of heights outside (O), inside (I) of the Pinus mugo nursery, and in the transition zone $(\mathrm{T})$.

spectively. All stands differed significantly only for coverage of $N$. stricta, for A. flexuosa they differed significantly for I-O and I-T stands, and for $C$. bigelowii in I-O only. Differences in coverage for other plant species among the investigated stands were not significant.

\section{Compressed sward height}

Mean compressed sward height was $12,11.9$, and $8.5 \mathrm{~cm}$ in I, O, and T stands, respectively, and differed significantly only between I and $\mathrm{O}$ plots (Table 2, Fig. 3). The range calculated as the difference between maximum and minimum sward height recorded in each relevé was more than four times lower in relevés collected inside the nursery than in other stands. The mean range of sward heights was $2.88,12.5$, and $13 \mathrm{~cm}$ in $\mathrm{I}, \mathrm{O}$, and $\mathrm{T}$ stands respectively. I-O and I-T stands differed significantly.

TABLE 2. Results of ANOVA analyses of cover estimates and compressed sward heights inside, outside and in the transition zone of the nursery. Tukey HSD - indicate significant differences between investigated areas, I - inside of nursery, O - outside of nursery and T - transition zone. Significant results are bold faced. Degrees of freedom were 2 in all performed analyses.

\begin{tabular}{|c|c|c|c|}
\hline Variable & F-ratio & P-value & Tukey HSD \\
\hline Nardus stricta & 155.2 & $<0.001$ & $\mathrm{I}-\mathrm{O}, \mathrm{I}-\mathrm{T}, \mathrm{O}-\mathrm{T}$ \\
\hline Avenella flexuosa & 10.8 & $<0.001$ & $\mathrm{I}-\mathrm{O}, \mathrm{I}-\mathrm{T}$ \\
\hline Carex bigelowii & 5.0 & 0.015 & $\mathrm{I}-\mathrm{O}$ \\
\hline Luzula sudetica & 0.9 & 0.454 & \\
\hline Deschampsia cespitosa & 2.4 & 0.129 & \\
\hline Calamagrostis villosa & 0.7 & 0.541 & \\
\hline Anthoxanthum alpinum & 2.5 & 0.1 & \\
\hline Total coverage & 12.7 & $<0.001$ & $\mathrm{I}-\mathrm{O}, \mathrm{I}-\mathrm{T}$ \\
\hline Sward height & 4.0 & 0.041 & $\mathrm{I}-\mathrm{O}$ \\
\hline Sward height - range & 58.7 & $<0.001$ & I-O, I-T \\
\hline Number of species & 1.06 & 0.361 & \\
\hline
\end{tabular}


TABLE 3. Results of the RDA analyses of cover estimates in $17.65 \mathrm{~m}^{2}$ plots.

Explanations: $\%$ axis 1 (all) - \% species variability explained by axis (all) - measure of the explanatory power of the explanatory variables, F - F-ratio statistics for the test on the trace (all axes). $\mathrm{P}$ - corresponding probability value obtained by the Monte Carlo permutation test (499 permutations, i.e. Type I error probability in testing the hypothesis that effect of one (all) explanatory variables is zero. I - inside; O - outside; T - transition zone.

\begin{tabular}{lcccc}
\hline Analysis I. & Explanatory variables & Covariables & \% axis 1 (all) & F 1 (all) \\
\hline 1. & I, O, T & Triplet & $70.3(72.6)$ & $42.5(23.9)$ \\
2. & I, O & Triplet, T & 49.7 & 17.8 \\
3. & T, O & Triplet, I & 31.7 & $0.002(0.002)$ \\
4. & T, I & Triplet, O & 71.7 & 0.002 \\
\hline
\end{tabular}
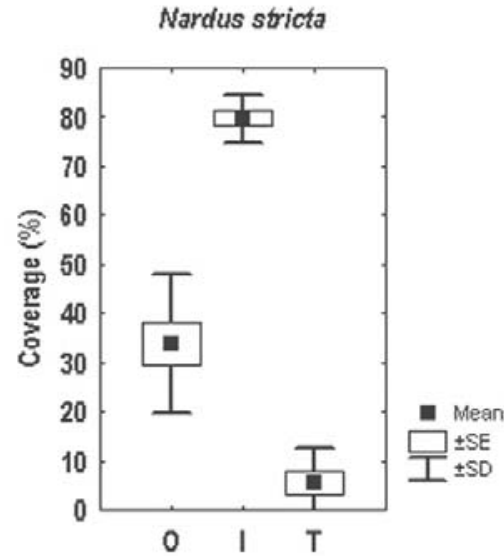

Deschampsia cespitosa

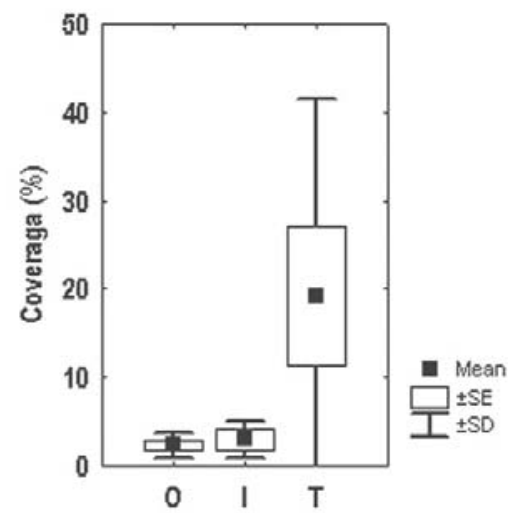

Avenella Hiexuosa
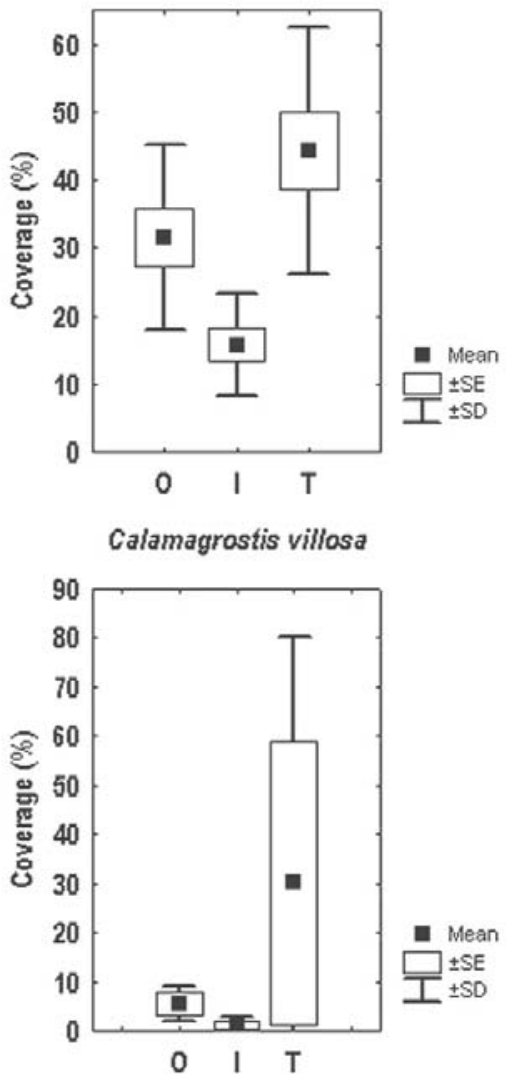

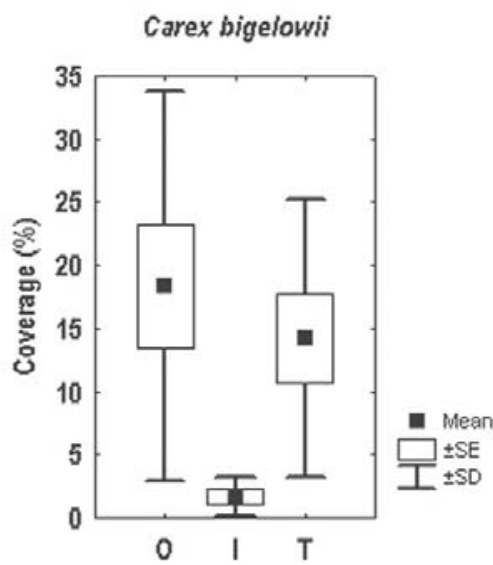

Luzula sudetica

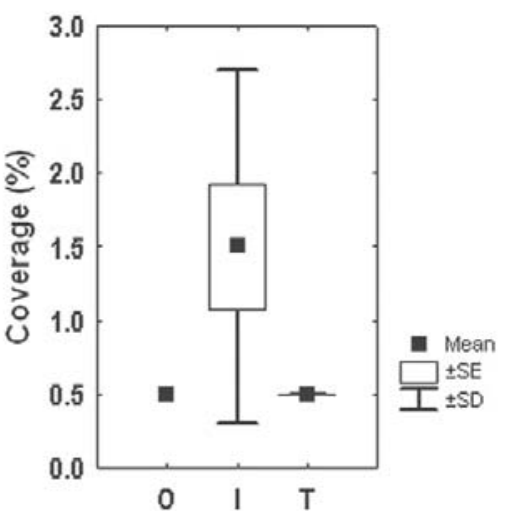

Fig. 4. Coverage of the most abundant species outside (O), inside (I) of the Pinus mugo nursery, and in the transition zone (T).

\section{DISCUSSION}

Dense sward dominated by $N$. stricta inside the nursery is a doubtless evidence of generative reproduction of this species in subalpine conditions of the Giant Mountains. The spread of $N$. stricta swards is very slow and according to Štursová (1985) does not represent the way of bare ground colonization. In the case of our nursery, the vegetative spread of $N$. stricta from outside was impossible from the practical point of view, because mat grass occurred sporadically in the majority of plots in the transition zone. Basing on the study of historical photographs, we concluded that the generative reproduction of $N$. stricta had been possible also in the period 1908-1952. A continuous N. stricta sward, but less dense than today, was well visible from photographs taken there before reestablishment of the nursery in 1952 (not published here). The next, even though indirect evidence for $N$. stricta generative reproduction is its caryopses germination estimated by Málková \& Matějka (2004). Caryopses collected in the vicinity of our study area showed a high year-to-year variability in germination, approximately from 5 to $80 \%$ from 1994 to 2001. It is obvious, that at least a part of caryopses was able to germinate in each investigated season.

The sward was homogenous inside of the nursery and coverage of $N$. stricta varied from 70 to $85 \%$ there. Variation was higher in the transition zone and highest outside the nursery. Coverage of N. stricta ranged from 0.5 to $22 \%$ in $\mathrm{T}$ stand and from 15 to $55 \%$ in O stand. The low variability of $N$. stricta coverages inside the nursery is an indicator of relatively homogenous conditions for germination and seedlings survival during the succession of abandoned arable land. The best indicator of sward homogeneity inside each relevé was the range of sward heights. That is why we performed 10 sward-height measurements per relevé instead of only one for species coverages. The variability of mean compressed sward height was similar on $\mathrm{O}$ and I stands and highest in T stand, as is seen in Figure 3. To know the variability within each collected relevé, we calculated height ranges for each sample, it means, by taking the maxi- 
mum minus minimum sward height from 10 measurements. The mean range of only $2.8 \mathrm{~cm}$ in I stand is in sharp contrast with 12.5 and $13.0 \mathrm{~cm}$ in other stands. The range heights are a good indicator of sward homogeneity and species distribution there. Relevés were patchy in both $\mathrm{T}$ and I stand and patches were composed of areas dominated by single species. Sward heights $2-5 \mathrm{~cm}$ were frequently recorded in patches dominated by $C$. bigelowii, on the other hand, heights $20-30 \mathrm{~cm}$ were measured in patches of C. villosa. The range of sward heights is thus a good indicator of variability in plant species composition in the investigated stands. The sward inside the nursery I was homogenous in comparison to swards of $\mathrm{T}$ and $\mathrm{O}$ stands. $\mathrm{Re}-$ establishment of other species characteristic for Carici fyllae-Nardetum grassland was also possible, as is evident from their coverages in I stand. We are not able to separate generative and clonal reproduction for these species and thus the discussion of generative reproduction is impossible. Clonal spread by long underground rhizomes, for example, is characteristic for C. villosa and C. bigelowii (Morávková 1999; Brooker et al. 2001).

A. flexuosa, C. villosa, and D. cespitosa had the highest coverage in the transition zone. It can be explained by highest nutrients availability of all stands caused by deposition of sods removed from the nursery during establishment in 1905 and reestablishment in 1952. Luzula sudetica was the most frequent in I stand, and is generally the most common in the dense $N$. stricta sward above the upper tree limit. It seems that homogenous vegetation inside the nursery was a more favorable environment for these species.

\section{Synthesis and application}

More than 300 ha of Carici fyllae-Nardetum grasslands on both the high-elevated plateaus of the Giant Mountains were considered by many authors as secondary, where plots of Pinus mugo were destroyed (Lokvenc 1960, 1978, 2001; Jeník 1961). According to Štursová (1985) N. stricta is unable to reproduce generatively above timber line, and thus she considered the large area of this grassland as natural communities. She concluded that this area was only partly enlarged in result of anthropogenic impact in the not too distant past. The inability of $N$. stricta generative reproduction was shown on abandoned roads and trenches, which were colonized by other species, not by $N$. stricta. Basing on results of our study we concluded than $N$. stricta is able to reproduce generatively in the subalpine conditions of Giant Mountains. Agricultural activities performed there for at least 500 years could support the spread of this species.

\section{ACKNOWLEDGEMENTS}

The study was supported by grant GAČR 526/03/0528. We thank the Krkonoše Park Administration for technical support. We are grateful to Dr. František Krahulec, Dr. Jan Štursa, Prof. Jan Jeník and two reviewers for their useful comments.

\section{LITERATURE CITED}

BROOKER R.W., CARLSOON B.A. CALLAGHAN T.V. 2001. Carex bigelowii Torrey ex Schweinitz (C-rigida Good. non Schrank; C-hyperborea Drejer). J. Ecol. 89: 1072-1095.
CORRELL O., ISSELSTEIN, J., PAVLU゚ V. 2003. Stydying spatial and temporal dynamics of sward structure at low stocking densities: the use of an extended rising-plate-meter method. Grass and Forage Sci. 58: 450-454.

FABISZEWSKI J., WOJTUŃ B. 2001. Contemporary floristic changes in the Karkonosze Mts. Acta Soc. Bot. Pol. 70 (3): 237-245.

HEJCMAN M., PAVLŮ V., PETEROVÁ J., ŘIČǍ̌OVÁ P. 2003. The expansion of Calamagrostis villosa in the Giant Mountains - Preliminary results. Acta Agrar. Silv. 60: 139-152.

HENDRYCH R. 2001. Květena-Krkonoš zvláště - pred čtyřmi staletími. Preslia 73: 29-58. (in Czech)

JENÍK J. 1961. Alpínská vegetace Krkonoš, Kralického Snežníku a Hrubého Jeseníku. Academia, Praha. (in Czech)

KRAHULEC F., 1985. The chorologic pattern of European $\mathrm{Na}$ rdus-rich communities. Vegetatio 59: 119-123.

KRAHULEC F., BLAŽKOVÁ D., BALÁTOVÁ-TULÁČKOVÁ E., ŠTURSA J., PECHÁČKOVÁ S., FABŠIČOVÁ M. 1996. Louky Krkonoš: rostlinná společenstva a jejich dynamika. Opera Concortica 33: 3-250. (in Czech)

KUBÁT K., HROUDA L., CHRTEK J. JUN., KAPLAN Z., KIRSCHNER J., ŠTĚPÁNEK J. (eds) 2002. Klíč ke květeně České Republiky. Academia, Praha. (in Czech)

LOKVENC T. 1960. Krkonošské hřebeny. Nakladatelství krajského domu osvěty. Hradec Králové. (in Czech)

LOKVENC T. 1978. Toulky krkonošskou minulostí. Kruh. Hradec Králové. (in Czech)

LOKVENC T. 1983. Počátky zalesňování v pásmu kleče. Krkonoše 16 (5): 16-19. (in Czech)

LOKVENC T. 1996. Klečový vegetační stupeň a jeho problémy. In: Vacek S. (ed.). Monitoring, výzkum a management ekosystémů na území Krkonošského národního parku. Výzkumný ústav lesního hospodářství a myslivosti. Opočno 224-228. (in Czech)

LOKVENC T. 2001. Budní hospodářství Labské louky. Z Českého ráje a Podkrkonoší 14: 69-90. (in Czech)

MÁLKOVÁ J., MATĚJKA K. 2004. Klíčivost vybraných travních dominant Krkonoš. Opera Corcontica 41: 250-255. (in Czech)

MATUSZKIEWICZ W., MATUSZKIEWICZ A. 1975. Mapa zbiorowisk roślinnych Polski. Warszawa. (in Polish)

MORÁVKOVÁ K. 1999. Vybrané problémy z biologie a ekologie třtiny chloupkaté (Calamagrostis villosa (CHAIX) J. F. GMELIN) v imisné postižené oblasti Jizerských hor. Sborník Severočeského muzea - Př́ŕrodní vědy 21: 53-94. (in Czech)

PAVLŮ V., HEJCMAN M., PAVLŮ L., GAISLER J. 2003. Effect of rotational and continuous grazing on vegetation of an upland grassland in the Jizerské hory Mts., Czech Republic. Folia Geobot. 38: 21-34.

SOUKUPOVÁ L., KOCIÁNOVÁ M., JENÍK., SEKYRA J. (eds) 1995. Arctic-alpine tundra in the Krkonose, The Sudetes. Opera Corcontica 32: 5-88.

ŠTURSA J. 1983. Poušt' na hřebenech. Krkonoše 16 (2): 16-19. (in Czech)

ŠTURSOVÁ H. 1974. Příspěvek k ekologii porostů smilky tuhé (Nardus stricta L.) v Krkonoších. Opera Cortontica 11: 79-129. (in Czech)

ŠTURSOVÁ H. 1985. Antropické vlivy na strukturu a vývoj smilkových luk v Krkonoších Opera Corcontica 22: 79-120. (in Czech)

TER BRAAK C.J.F., ŠMILAUER P. 1998. CANOCO Release 4. Reference manual and user's guide to Canoco for Windows; Software for Canonical Community Ordination. Microcomputer Power, Ithaca.

WÁGNEROVÁ Z. 1991. Rostlinná společenstva Kotelních jam jižního svahu Krkonoše v rozmezí let 1968-1990. Ms. Habilit. Thesis, depon. In: Přír. Fak. MU Brno. (in Czech) 